\title{
"I'm not my disease": the choice to talk about their cancer experience by common women or female celebrities
}

\author{
Alfredo Tartarone* and Rosa Lerose \\ Unit of Medical Oncology, Department of Onco-Hematology, Hospital Pharmacy, IRCCS-CROB Referral Cancer Center of Basilicata, Rionero in Vulture (Pz), \\ Italy
}

\begin{abstract}
For many reasons the diagnosis of cancer has generally a stronger impact in women than men. However, nowadays women with cancer may learn to deal with their fear in different ways including a better knowledge of the illness, a good doctor-patient relationship and the sharing of their personal experiences.
\end{abstract}

Women who receive a diagnosis of cancer are more vulnerable than men also because they fear particularly the impact of disease and therapies on their physical appearance and quality of life [1].

However nowadays women with cancer may learn to deal with their fear in different ways. Firstly, considering that the majority of patients want to know as much as possible about their illness, an effective doctor-patient communication could play a crucial role $[2,3]$. In fact, a good doctor-patient relationship may reinforce patients' motivation and increase the adherence to the treatment [4]. Moreover, the patient will be informed by the doctor that the side effects of cancer therapy, including the feared alopecia, actually may be more effectively managed, as well as in many cases the reconstructive surgery can help to reshape the self-image [5].

Another possible way to defeat the cancer taboo includes the sharing of personal experiences, as evidenced by numerous testimonies of both common women and the so-called celebrities. Among the many celebrities who decided to publicize their experience with cancer we remember the former Italian Foreign Minister Emma Bonino and the actress Angelina Jolie, two of the 150 women who shake the world according to the magazine Newsweek [6]. On January 2015 Emma Bonino announced that she was undergoing treatment for a lung tumour using these words "I am not my tumour and you are not your illnesses, we must only think that we are people that face a challenge that arises". During the chemotherapy treatment she continued her political activity without fear of appearing in public wearing a turban to hide her alopecia. The "Angelina Jolie effect" on breast screening is well known to researchers [7-10]. This pattern has been coined when the actress in a 2013 New York Times editorial urged women to consider BRCA 1-2 genetic testing and revealed that she had undergone preventive double mastectomy. The article achieved a great resonance in the media, raising interest on the matter over the world. In 2013 in UK, also due to the "Angelina Jolie effect", there was a release of the National Institute of Health and Care Excellence (NICE) guidelines on familial breast cancer [11]. For what concerns common women, some associations of patients (eg. Susan G. Komen, Europa Donna) publish their personal experiences $[12,13]$. In these stories on the one hand they reveal the desire to share their emotions and hopes, on the other hand they show the need to claim fundamental rights such as the access to the best available care or the possibility of being able to keep working or come back to work.

Other initiatives, such as "The Komen Race for the Cure" that involves many thousands of participants each year in the world with more than 130 races, can also be useful not only to raise funds for research but also to be more informed and proactive against breast cancer [14].

In conclusion a better knowledge of the illness, a good doctorpatient relationship and the sharing of personal experiences may help women to conduct their battle against cancer without fear or shame.

\section{Conflict of interest statement}

None by all authors.

\section{References}

1. Pierrisnard C, Baciuchka M, Mancini J, Rathelot P, Vanelle P et al. (2018) Body image and psychological distress in women with breast cancer: a French online survey on patients' perceptions and expectations. Breast Cancer 25: 303-208. [Crossref]

2. Cao W, Qi X, Yao T, Han X, Feng X (2017) How doctors communicate the initial diagnosis of cancer matters: cancer disclosure and its relationship with patients'hope and trust. Psycho-Oncology 26: 640-648.

3. Oskay-Ozcelik G, Alavi S, Richter R, Keller M, Chekerov R, et al. (2018) EXPRESSION III: patient's expectations and preferences regarding physician-patient relationship and clinical management. Results of the international NOGGO/ENGOTov4-GCIG study in 1,830 ovarian cancer patients from European countries. Ann Oncol 29: 910-916. [Crossref]

4. Ha JF, Longnecker N (2010) Doctor-patient communication: a review. Ochsner $J 10$ : 38-43. [Crossref]

5. Rugo HS, Voigt J (2018) Scalp hypothermia for preventing alopecia during chemotherapy. A systematic review and meta-analysis of randomized controlled trials. Clin Breast Cancer 18: 19-28. [Crossref]

${ }^{*}$ Correspondence to: Alfredo Tartarone, Unit of Medical Oncology, Department of Onco-Hematology, Hospital Pharmacy, IRCCS-CROB Referral Cancer Center of Basilicata, Rionero in Vulture (Pz), Italy, E-mail: tarta1@virgilio.it

Received: July 09, 2018; Accepted: July 20, 2018; Published: July 24, 2018 
Tartarone A (2018) “I'm not my disease": the choice to talk about their cancer experience by common women or female celebrities

6. http://www.newsweek.com/2011/03/06/150-women-who-shake-the-world.html

7. Mao J, Jorm L, Sedrakyan A (2017) Trends in use of risk-reducing mastectomy in a context of celebrity decisions and media coverage: an observational study in the United States and Australia. Health Serv Res. [Crossref]

8. Borzekowski DL, Guan Y, Smith KC, Erby LH, Roter DL (2014) The Angelina effect: immediate reach, grasp, and impact of going public. Genet Med 16: 516-521. [Crossref]

9. Kamenova K, Reshef A, Caulfield T (2014) Angelina Jolies's faulty gene: newspaper coverage of a celebrity's preventive bilateral mastectomy in Canada, the United States, and the United Kindom. Genet Med 16: 522-528. [Crossref]
10. Desai S, Jena AB (2016) Do celebrity endorsements matter? Observational study of BRCA gene testing and mastectomy rates after Angelina Jolie's New York Times editorial. BMJ 355: 16357.

11. Evans DG, Barwell J, Eccles DM, Collins A, Izatt L, et al. (2014) The Angelina Jolie effect: how high celebrity profile can have a major impact on provision of cancer related services. Breast Cancer Res 16: 442. [Crossref]

12. https://www.voltatiguardaascolta.it

13. https://ww5.komen.org/StoriesofInspiration.htm

14. https://ww5.komen.org/RaceForTheCure/

Copyright: $@ 02018$ Tartarone A. This is an open-access article distributed under the terms of the Creative Commons Attribution License, which permits unrestricted use, distribution, and reproduction in any medium, provided the original author and source are credited. 